Vol. XXI - REVISTA DE HISTÓRIA - Ano XI

\title{
CONFERENCIAS
}

\author{
ALGUNS ASPECTOS DAS REI.AÇÕES DO \\ OCIDENTE COM O EXTREMO ORIENTE \\ DURANTE A ANTIGUIDADE \\ E A IDADE MEDIA (**).
}

Escolhemos como assunto para a nossa exposição o seguinte tema: "Alguns aspectos das relações do Ocidente com o Extremo-Oriente durante a Antigüidade e a Idade "Média".

Inicialmente temos que explicar aos presentes o porquê da escolha dêste tema. Se prestarem atenção ao que se passa no nosso planeta, verão que o Extremo Oriente possui atualmente mais da metade da população do globo e a sua importância está crescendo cada vez mais no mundo atual. Estamos vendo o Japão, a China e a fndia tomarem o papel que lhes cabe, não só devido aos seus recursos materiais, mas também cos imensos contingentes humanos que possuem.

Muita gente ainda pensa que Ocidente e Oriente sempre foram dois mundos antagônicos, com as costas voltadas um para o outro. Se os senhores verificarem a História durante a Antigüidade e a Idade Média verão que êstes dois mundos há muito se conheceram. Não houve um entrelaçamento muito grande, mas no mundo antigo 'e medieval êles se entenderam talvez melhor que do que ëm nossos dias. Daí o tema de hoje: "Alguns aspectos das relações do Ocidente com o Extremo Oriente durante a Antigüidade e a Idade Média".

E' com Dario I que temos notícias certas, seguras, sôbre a India. Dario dividiu o seu Império em satrápias. O Império aquẹênida fêz sentir no território por êle ocupado a sua cultura, principalmente através das estradas reais, sistema desenvolvido por Dario, talvez aproveitando velhos caminhos de antigas civilizações. Uma dessas estradas ligava Babilônia à fron-

(*). Aula proferida no Salão Nobre da Faculdadé de Filosofia, Ciências e Letras da Universidade de São Paulo em 16 de março de 1960. (Nota da Redação). 
teira indú. E para que se tenha uma idéia da importância do impacto persa sôbre a fndia, basta dizer que essa influência se fêz sentir durante 200 anos.

Da época de Dario temos um texto grego muito interessante: o de um oficial helênico ao seu serviço - Cilax de Carianda que foi enviado por êle para reconhecer a India em 519 a. C. Este grego percorreu a fronteira e tornou-se almirante persa do Mar fndico, tendo publicado um livro sôbre a sua viagem, denominado Périplo. Com essa obra, pela primeira vez, o Ocidente tomou conhecimento, mais ou menos certo, dêsse mundo novo, completamente ignorado até então.

Temos em seguida as Guerras Médicas. Nessas Guerras, na batalha de Maratona, os gregos lutaram contra soldados indús. Depois da vitória dos atenienses chegaram os espartanos ao campo da luta. Com surprêsa viram bárbaros para êles completamente desconhecidos, indivíduos com couraças de algodão, flexas e arcos de bambú. Eram os indús que serviam nos exércitos aquemênidas e que agora os gregos viam pessoalmente ao defenderem sua liberdade. Ésses cadáveres indús mostravam a existência de um mundo diferente para a população da Hélade.

No $\mathrm{V}$ século, através da ciência grega, tomamos conhecimento dêsse mundo exótico. Heródoto de Halicarnasso apoiou-se principalmente em Hecateu de Mileto, que tinha descrito a fndia. Temos aí uma amostra de uma curiosíssima geografia: a Grécia era o centro do mundo, o Mediterrâneo unia a Europa à Ásia e África. Heródoto, apoiado em Hecateu, dizia que o clima da Índia Oriental era tórrido de manhã, quando nascia o sol, e quando o sol estava a pino, muito alto, a temperatura amenizava.

No IV século temos Ctésias que, no seu trabalho História dos persas, narra as maravilhas da fndia.

$\mathrm{E}$ quando entramos no período helenístico, as relações se tornam mais intensas e mais intimas. Nas tropas que lutaram contra Alexandre, tropas de Dario III, havia indús e mesmo elefantes asiáticos com os seus cornacas e Alexandre, na sua marcha através da Ásia, chegou até a fronteira da India onde esbarrou com a resistência indú e principalmente com a oposição dos seus soldados que não queriam ir mais além.

Para essa fndia marchou êle com um exército de 120.000 homens, contando apenas 40.000 combatentes. O resto era composto de indivíduos que iam exercer nas cidades que êle fundava, diversas profissões. Alexandre combate apoiado em Taxila e seus 56 elefantes, contra o rajá Poros (Paurava) na 
batalha do Hidaspes. Depois começou a sua Odisséia com a descida do rio Indo e, através do deserto de Gedrósia, atingiu Babilônia. Foi o almirante Nearco, que fêz um périplo pelo fndico, quem nos descreve as grandes marés. Viu num imenso Oceano, baleiàs esguichando água.

Alexandre organizou a fndia à maneira dos aquemênidas, criando diversas satrápias e, quando partiu de volta, ocorreram revoltas que logo terminaram com o domínio macedônico. As equipes que êle organizou não conseguiram implantar de pronto o predomínio helênico. $\mathrm{E}$ no rio Ganges, nesse momento, há um centro de budismo muito importante e dêsse local vemos partir uma vaga de nacionalismo contra o estrangeiro. $E$ logo após temos a volta do vale do rio Indo à civilização bramânica. Mas, ficou aí alguma coisa de Alexandre. Ele fundara inúmeras cidades e êsses centros não morreram de todo. Na Bactriana, centros de helenismo vão perdurar durante séculos, dando origem à famosa arte greco-búdica.

Assim, com a expulsão dos gregos por Çandragupta sobe ao poder a dinastia dos Maurias. O seu neto é um grande monarca, bastante conhecido. Açoca (264-226 a. C.) é um imperante que reuniu uma grande porção do território indú, desde a Aracósia até Bengala, do Afagnistão ao Misore. E êsses acontecimentos são contemporâneos das famosas guerras Púnicas no Mediterrâneo Ocidental.

Êsse período é muito interessante porque, ao mesmo tempo em que os Maurias se ocupam com a unificação da fndia, na Chira temos uma nova dinastia que foi implantada a ferro e fogo por Che-Hoang-Ti. Temos então conhecimento, através dos textos indús, dessa velha China que começa a aparecer aos nossos olhos.

Os gregos da Bactriana, curiosamente, depois de muito tempo, invadem a Índia no II século a. C. e vão até as portas da cidade de Magada, que ficou como capital do novo reino por êles criado. Mais tarde foram dispersados pelos indo-citas, que dominaram a fndia do Oeste, Afagnistão e Asia Central e as rotas da Alta-Ásia para a China. Essa conquista greco-bactriana tem grande importância, pois foi através dela que a cultura grega se fêz sentir na civilização indú. Da importância dêsse impacto cultural são belas provas os diversos espécimes da arte greco-búdica que conhecemos. Os budistas, que nessa época já tinham dominado o vale do rio Indo, vindo do Ganges, impressionaram-se com os motivos plásticos gregos. Muitas estátuas 
de Buda tem características helênicas bem visíveis. Notamos também essa influência nas moedas. Os indús começaram a cunhar moedas imitando as macedônicas. Elas foram introduzidas na fndia pelos gregos da Bactriana, talvez muito antes da conquista que êles fizeram da península hindustânica.

Temos, nesse período, dois centros importantes de difusão cultural - a f́ndia e Roma. Esta já dominava o Mediterrâneo, já se tinha imposto a Alexandria, Síria e Macedônia, que até então tinham tido a primasia política e cultural da bacia mediterrânea oriental. Esstes dois centros têm relações comerciais com diversas partes do mundo conhecido de então. Conhecemos textos indús e textos greco-latinos mostrando êsses contactos. Segundo um autor inglês, S. Warmington, no ano 42 a. C., relações comerciais estavam bem estabelecidas entre o Mar Vermelho e a Ásia. 'A rota da India estava aberta ao comércio. Sabia-se que as monções sopravam em certo momento num sentido e depois, numa outra época, em sentido contrário. Podia-se pois, perfeitamente, saindo do Mar Vermelho, atingir a costa do Malabar e voltar dentro de um ano.

Estrabão atesta que em 24 a. C. Hélio Galo, prefeito do Egito, assistiu a partida de uma grande frota de 120 navios, rumo à India. São provàvelmente mercadores de Alexandria, sírios e egípcios, que sempre se distinguiram pela aventura do comércio. Iam em busca da canela. Êste produto, que era um dos mais importantes dêsse tráfico, era produzido no Ceilăo, o que indica já haver um comércio regular na fndia com a região do Mar Vermelho. Há uma região citada por Estrabão, muito longínqüa, Cinamomoforia, que seria Taprobana, ou uma terra mais ao sul para Plínio. Talvez êsse comércio atingisse a Indochina, terra da canela. E sabemos que os indús transportavam o cinamono - essa árvore odorífera - para escambo cóm os mercadores do Ocidente. Temos prova dêsse tráfico na arqueologia tanto da Conchichina çomo da fndia, como na própria Itália.

Assim, estabeleceu-se grande intercâmbio entre o mundo romano - através do Egito - e a fndia. Mercadores de Alexandria encontravam-se com marinheiros de várias regióes da fndia. Também o árabe já aparece nesse tráfico. Indús e cingaleses costumavam vir ao Ocidente e também os egípcios e sírịos iam à região do Malabar e Taprobana.

Textos budistas falam do comércio marítimo indú. Nầo é só entre os ocidentais que encontramos referềnciàs a êssé 
comércio. Ésses textos budistas falam de navios de duas proas, com capacidade para três mil ânforas, o que daria mais ou menos 75 toneladas de arqueação. Durante quatro meses êles deixavam de navegar e durante os outros oito 'navegavam de um lado para outro, usando pássaros que buscavam a terra mais próxima como guia para as embarcações.

Em Plínio encontramos dados interessantes. Fala numa embaixada cingalesa que veio ao Ocidente, em virtude de um liberto do arrendatário do comércio do Mar Vermelho ter ido à India e despertado tanto interêsse que resolveram retribuir a visita. Os tamuls do Coramandel possuiam frotas e navegavam rumo ao litoral da Indonésia e Indochina. E êsse comércio se intensifica cada vez mais.

Antes disso, temos também referências precisas dêsse comércio na época de Augusto. O Imperador recebeu duàs embaixadas indús. Uma em l'arragona, em 25 a. C. e outra, no ano 20 a. C., na ilha de Samos.

Segundo Plínio, o comércio do Egito com a fndia era mais ou menos de 150 milhões de sestércios. Já é uma soma bem ponderável. Verifica-se por outro lado que a balança de comércio sempre é favorável aos orientais. Êstes têm mais coisas a exportar do que a receber, e a prova disto está no grande número de tesouros contendo moedas de ouro romanas encontrados na india. Esses tesouros de moedas romanas são de diversas épocas e as peças apresentam as efígies dé diversos imperadores. Isto prova que os romanos pagavam a maioria das suas importações em metal e não em mercadorias, ficando pois bem patente que a balança de comércio pendia sempre para o lado do Oriente.

Entretanto, entre as mercadorias exportadas do lado romano, o coral foi tạ̃o importante que em certo momento tornou-se coisa rara no mundo ocidental ، $O$ vinho foi também bastante exportado e o mercenário grego era muito procurado, pois tratava-se de uma máquina de guerra muito eficiente. Do lado oriental a pimenta - trazida às feitorias de exportação em canoas monóxilas - avultava cada vez mais.

Também, como aconteceu com a moeda helênica, a moeda romana influiu na cunhagem de peças indús. Há diversas moedas hindustânicas que são a reprodução exata das moedas dêsses períodos de explendor da expansão imperialista de Roma pelo mundo mediterrâneo e regiões circunvizinhas.

- Vejamos agora, com mais vagar, as rotas marítimas e terrestres que ligavam a fndia a Mar Vermelho. 
Segundo Estrabão, os mercadores partiam do Nilo para o Mar Vermelho; daí êles embarcavam sua pacotilha no pôrto de Miosormos e escalavam em Coptos; dêsse local, então, iniciavam a viagem marítima - aproveitando as monções - rumo às costas da fndia. Isto segundo Estrabão. Plínio é mais preciso. Fala numa escala na Arábia. Os mercadores partiam de Alexandria, atingiam Juliópolis no Nilo e daí rumavam para Coptos, $\epsilon$ nisso levavam doze dias. De Coptos a Berenice gastavam mais 12 dias. De Berenice a Ocelis, na Arábia, mais trinta dias. De Ocelis a Muziris, na fndia, mais 40 dias. São, portanto, três meses para ir de Alexandria até a costa do Malabar. Voltavam por ocasião da canícula e nos idos de janeiro chegavam ao Egito. Descontando-se os quatro meses em que não se navegava, temos uma estada possível de dois meses na India. Assim, a frota que partisse pelo Mar Vermelho podia ficar dois meses na fndia e voltar. Nestas condições não poderia haver aí estabelecimentos permanentes ou relações muito intensas. Provàvelmente apareceram feitorias para a concentração da carga a embarcar, como fizeram inicialmente os portuguêses mais tarde e na mesma região. Um ou outro funcionário ficava por aí e assim que chegava a frota tratava de embarcar a mercadoria e propiciar a volta da esquadra romana para o Egito. Alguns autores sustentam que êsses funcionários romanos seriam sírios ou egípcios e que eram permanentes nesses portos de embarque.

Mas há também uma rota terrestre. Mercadores e caravidrias passavam por Petra procurando atingir a Arábia Nabatéia ou Palmira, antes da intervenção romana. Daí rumavam para a Síria e desembarcavam seus fardos diretamente no Mediterrâneo, sem passar por Alexandria. Há diversas rotas com pontos de chegada diferentes. Também encontramos uma rota fluvial através do gôlfo Pérsico e Arábia Nabatéia procurando atingir as costas do Mediterrâneo.

Existia também uma outra rota fluvial muito interessante, através do rio Oxus, que separa a Bactriana da Sogdiana, atingindo o Mar Cáspio e chegando ao Ponto Euxino. O magnífico livro de Foucher, La vielle route de l'Inde de Bactras à Taxile, uma obra muito interessante, faz um amplo estudo da rota, suas etapas, as peagens, etc, E' a famosa rota da sêda: êsse caminho destinado não só a transportar mercadorias da fndia, como também outras vindas da região chinesa. Uma prova dêsse comércio são os objetos da arte greco-budista do Gandara. E a arte grega, influenciando o budismo, penetrou até na própria China. Podemos também sentir a importância da in- 
fluência dos mercados do Extremo Oriente nas ruínas de Palmira.

$\mathrm{Na}$ China os Anais dos Har posteriores mencionam o comércio da fndia e China com o Império Romano, referido aí como o Império de Ta-T'sin. Posteriormente os próprios chineses tentaram entrar em contacto com o mundo romano. Mandaram uma embaixada chefiada pelo general Pantchao, entre $88 \mathrm{e}$ 105, que veio pela rota da sêda, mas como os partas lhe disseram estar o Império Romano muito longe, Pantchao voltou. As desordens que então eclodiram no Turquestão chinês, mais ou menos em 127 a. C., acabaram por arruinar essas tentativas de aproximação e contacto direto.

Falamos da fndia e seus depósitos arqueológicos. No Ocidente, na península itálica, em Pompéia, encontrou-se um cabo de espêlho que é evidentemente obra indú. Em Gandara, na fndia, encontramos restos de cerâmica de Arretium (Arezzo), na Itália. Perto de Pondichéry, na Índia, encontrou-se restos de uma cidade - Virapatnam (aldeia de heróis) - , ruínas cheias de restos de comércio com o Ocidente; ruínas de oficinas, restos de rebolos, pedras de moer, pedras lapidadas, com evidentes traços da existência de uma oficina de lapidação. Ao lado disso, restos de ânforas romanas, cacos com marcas de ceramistas, etc. Além do mais, na Conchinchina, na cidade de Oc-éo, encontrouse cerâmica, cabuxões sassânidas, pastas de vidro. entalhes, moedas romanas, jóias indús de ouro, etc. Essa era justamente a região da canela. Plínio narra que um mercador para chegar a zona da canela levava cinco anos e hoje desconfiamos de que essa notícia foi difundida por interessados em aumentar o preço do produto.

Com o reinado de Marco Aurélio (161-180) - segundo alguns autores, isto se teria dado na época de Heliogábalo, no III século portanto - temos uma curiosa notícia: a chegada de uma embaixada de mercadores da India e Ceilão que ofereceu um acôrdo comercial ao Império Romano.

As trocas de mercadorias entre o Oriente e Ocidente tinham possibilitado também a troca de elementos culturais. Assim, por exemplo, temos na época da ocupação da fndia pelos gregos da Bactriana, o famoso livro Milindapañha (as perguntas do rei Menandro) que mostram como um rei grego (Menandro) converteu-se ao budismo, acreditando na extinção do ego.

$\mathrm{Na}$ ciência do Oriente encontra-se, evidentemente, traços da ciência grega. Na astronomia, astrologia, medicina, notamse elementos culturais típicos de Alexandria. No Ocidente ve- 
rificamos também influências indús, como por exemplo a doutrina dos agnósticos ou a de Plotino, o romance grego, a mística do Pseudo-Dionísio, as doutrinas de Orígenes, a eqüação logosanthropos e no famoso livro de Hipólito, chamado Philosophoumena (refutação de tôdas as heresias), vê-se a doutrina dos brâmanes de Tungabena perfeitamente identificada. Na Vida de Apolônio de Tiana, de Filostrato, aparecem os gimnosofistas da Etiópia que tinham repudiado os seus colegas da fndia, o que nos leva a acreditar que a filosofia indú era conhecida no Ocidente. Portanto, ao lado das relações comerciais temos tamhém as relações culturais.

Entre o Império Romano, a Índia e a China, como já dissemos, existia o Império Parta, que procurava, sempre que possível, ser o intermediário entre aquelas regiões e, em certas épocas, chegou mesmo a ditar os preços das especiarias. Retendo as mercadorias, os preços subiam em Roma. Assim, em diversos textos podemos verificar o valor da mercadoria numa época de paz e o seu 'valor em época de guerra. Quando a rota estava aberta ao comércio o preço das mercadorias baixava. Êsse fato talvez explique as diversas campanhas promovidas por Trajano no Oriente e a própria conquista da Dácia talvez signifique, a luta pela posse de jazidas auríferas necessárias para equilibrar a deficitária balança do comércio com o Extremo Oriente.

Durante o reinado de Constâncio foi publicada uma obra chamada Expositio totius mundi que descreve a totalidade do mundo romano e nela fala-se duma feira anual em Batnae, na região do Eufrates. Essa feira era interessante porque reunia mercadorias ocidentais e orientais, predominando o comércio da sêda. A sêda chegava em tecidos ou em fios. Sabe-se que no III século uma libra de sêda valia uma libra de ouro. No IV século. uma libra de sêda valia um quarto de uma libra de ouro. O curioso é que a sêda tinta de púrpura valia duas libras e meia de ouro. Na feira negociava-se ainda marfim e pérolas.

No período medieval vai continuar e aumentar o escambo com o Extremo Oriente. Bizâncio era dominada por gregos e armênios: duas populações eminentemente comerciantes. "Era uma cidade cheia de bancos, armadores e comerciantes. As classes privilegiadas estavam acostumadas com o cravo da fndiá, a pimenta, a canela, ervas aromáticas, perfumes, pedras preciosas, pérolas, marfim, metais raros, sândalo, álgodão, álóes, cana de açúcar e a sêda da China. Para essas regiões exportavam os bizantinos produtos manufaturados e, principalmente, moedas de ouro, em virtude da deficitária balança do comércio. 
No período bizantino temos quase que as mesmas rotas que já examinamos anteriormente. As terrestres, vindo da China para a Asia Central, procuravam atingir Samarcanda, Bucara, casis da Sogdiana. Daí bifurcavam-se, uma através do Volga até Querson no Mar Negro (Rússia Meridional) e a outra através da Armênia, rumava para Trebizonda.

Em 532, segundo um acôrdo feito entre bizantinos e persas, as mercadorias orientais só podiam ser recebidas em três pontos: Calínico na Osroene, Nisibis na Mesopotâmia e Artaxata na Armênia.

A rota marítima trazia para o Império Bizantino mercadorias chinesas, malaias, indochinesas, que se concentravam em Ceilão, onde os persas as levavam para a Mesopotâmia e os abexins para Adulis no Mar Vermelho. Uma nota curiosa dêsse tráfico é a importância comercial que os abexins tiveram nessa época.

Justiniano (527-565) procurou acabar com o monopólio persa que tentava controlar todo o comércio oriental de Constantinopla. Os bizantino: utilizaram-se do pôrto de Aila, no gôlfo de Acaba, e em Jatoba (atualmente Tiran), no Sinai, estabeleceram 'um pôsto fiscal. Os abexins iam buscar em Ceilão as mercadorias e as traziam para aí. Justiniano procurava escapar assim da opressão dos persas, procurando uma rota marítima livre ao sul.

Essas relações dos abexins com Bizâncio têm também um aspecto religioso. Os abissínios, principalmente os da região de Axum, eram cristãos. A Abissínia entrou em luta contra o Iemen, onde tinha predominado a dinastia de Sabá e na época imperava a casa de Himiar, dinastia judia ou judaizante.

O resultado dessa luta entre árabes e abexins (530-531) que teve, como vimos, um aspecto religioso, foi a vitória sibissínia com o auxílio de Justiniano. Elles conquistaram a região do Temen e eliminaram os seus rivais e, assim, puderam traficar diretamente com Taprobana. Mas os persas não desistiram. Possuiam a maior colônia de mercadores da ilha de Taprobana e, dominando o mercado, não forneciam mercadorias aos abexins. Essa tentativa de Justiniano fracassou. Mais tarde, quando êle morreu, os persas conquistaram êsse reino do Iemen (570) e os abexins voltaram novamente à sua posição subalterna.

Ligado ao aspecto religioso temos o aspecto econômico da política de Justiniano.

- No Império Bizantino a sêda tinha enorme importância. A côrte tinha o hábito de se trajar com sêda, por isso 
as manufaturas de sêda são incrementadas. Mas, volta e meia c.s persas entravam em luta com os bizantinos. Conseqüentemente, o fornecimento de sêda era paralisado. Para se evitar êsse contratempo não havia remédio possível. A rota do sul (rota marítima) fôra cortada com a derrota abexim. A rota do norte ficava à mercê dos nômades que vagavam pelas estepes asiáticas. O fornecimento de sêda ao Império Bizantino era, pois, sempre uma aventura. Mas, por uma sorte fantástica, Bizâncio resolveu o problema. Segundo alguns autores, dois monges nestorianos trouxeram dentro de seus bordões de peregririos casulos do bicho da sêda. E êsses casulos proliferaram extraordinàriamente quando foram feitas grandes plantações de ámoreiras. E pouco a pouco Bizâncio foi melhorando de situação no que tange a fabricação de tecidos de sêda.

Em Beritos, Tiro, Antioquia e nas vizinhanças de Bizâncio estabeleceram-se grandes oficinas de fiação de sêda. Foi salvo, portanto, o comércio da sêda. Mas mesmo com essa fabricação, o comércio com o Extremo Oriente não desapareceu de todo, porque o consumo da sêda era muito grande. Pouco a pouco o Estado Bizantino monopolizou a manufatura da sêda. Sómente certas oficinas poderiam fabricar determinados tipos de tecidos e somente certas camadas sociais poderiam adquirir essa sêda. Era uma grande honra poder comprar um pedaço de sêda.

Os textos bizantinos mostram perfeitamente sinais de que o comércio com o Extremo:Oriente não morrera. Alguns dêles falam numa ametista que cintilava num templo do Ceilão, outros mostram rebanhos de elefantes vagando pelas savanas. Outro fala numa ilha de sátiros, provàvelmente por conter orangotangos e que seria talvez a ilha de Bornéu.

Contemporâneo de Justiniano é um escritor famoso: Cosmas Indicopleustes. Escreveu êle um livro chamado Topographia Christiana. Provàvelmente era alexandrino. Na: sua obra descreve as visitas que fêz ao Mar Negro, ao Sinai, à Etiópia e ao Ceilão. Esse livro foi escrito para provar que a terra não era ıma esfera, mas, sim, um retângulo e assemelhava-se ao tabernáculo de Moisés.

Mas, o curioso dêsse trabalho é que o texto é acompanhado de miniaturas feitas pelo autor mostrando como os indígenas do Ceilão e da fndia foram vistos por êsse monge nestoriano.

No tempo de Cosmas Indicopleustes os mercadores persas dominam os mercados da ilha de Ceilão e êle conta uma aneaota muito interessante de um mercador chamado Sopatro. Um 
persa e êsse Sopatro apresentaram-se a um régulo cingalês e os dois pleitearam o monopólio do comércio das especiarias. $\mathrm{O}$ régulo indú pergunta: Qual dos dois é que tem o rei mais poderoso? O persa diz que é o seu monarca, o rei dos reis. Volta-se o régulo e pergunta ao bizantino: - e você? Êle, então, tira da bôlsa uma moeda e diz: isto é que vale para mim; o meu rei é cste. Evidentemente o monarca deu preferência àquêle que tinha a moeda de ouro, o nomisma bizantino. Traprobana era dominada pelos persas, mas a moeda aí corrente era a de Bizâncio. Isto mostra que os persas faziam o comércio, não para usufruirem as especiarias, mas para vendê-las aos consumidores kizantinos.

Com Justino II (565-578) vamos ter uma tentativa curiosa: os turcos procuraram Bizâncio e ofereceram sua aliança contra os persas. O acôrdo seria o seguinte: êles canalizariam a rota da sêda pelo Mar Cáspio e êsse comércio não precisaria passar mais através da Pérsia. Um funcionário bizantino acompanhou as cmbaixadores até o Khan Dizaboulos, mas nesse momento desagregou-se o império dêsse régulo nômade. Desaparecido êle. esboroava o seu império, perdendo-se ótima oportunidade para o estabelecimento duma rota livre ao norte. Teria sido o grande sonho de Justiniano realizado pelo seu descendente..

Pouco a pouco o comércio bizantino através da Pérsia vai entrando em declínio devido à avalanche árabe $\mathrm{O}$ Islão domina a Pérsia e mutila o Império Bizantino. Apesar de tudo o comércio bizantino continua através de outras mãos.

Os árabes, dominando a região da Síria, prestaram um grande serviço aos bizantinos: liqüidaram a marinha síria e a marinha bizantina ficou sòzinha no Mediterrâneo Oriental. Os mercadores de Bizâncio passaram a não sofrer mais a concorrência levantina. A concorrência se faz agora sentir através dos árabes. Êstes levam consigo diversos elementos culturais à Índia e ao Ocidente, através do norte da Africa. Os árabes são os grandes fautores do contacto do mundo ocidental com o mundo do Extremo Oriente durante a Idade Média.

O Império Persa desapareceu, mas a rota da sêda ainda fni utilizada. Ela continuou a chegar até a região de Trebizonda. E' por isto que os mercadores italianos de Amalfi e Veneza procuram obter de Bizâncio o privilégio de canalizar o comér. cio das especiarias para o Ocidente, indo buscar em Trebizonda as mercadorias de que tinham necessidade. Durante um certo tempo assim se fêz. 
A rota norte estava livre, dependendo sempre de outros, como na época os vareques que, vindos do Báltico através da Rússia, dominam o Quersoneso.

Nos textos chineses fala-se emmercadorias árabes que teriam atingido a China. Os árabes continuaram a navegação dos indús e na época da dinastia T'ang, por exemplo, sabe-se que chegaram até o Japão e talvez até a região da Coréia.

No século XII temos o aparecimentos de outro elemento que penetrou fundo no comércio das especiarias: os normandos, que vão rivalizar comercialmente com os italianos em Trebizonda e no Mediterrâneo Oriental. Mais tarde surgiu o Império Latino do Oriente de 1204 a 1260 por obra de Veneza que, apoiada nos cruzados ocidentais, busca o monopólio do comércio oriental. Assistimos de outro lado a restauração do Império Bizantino pelos Paleólogos com o apôio dos genoveses.

Mas já no século XII os normandos chefiados por Rogério, єm 1147 precisamente, dominam Tebàs e Corinto e levam o bicho da sêda para a Itália. E da Itália êle se propagou pela Europa.

No século XII são os italianos que dominam o comércio das especiarias. Mais tardes os portuguêses procurarão estabelecer uma rota com o Oriente, mas já agora fazendo a circunavegação da Africa.: O Infante Dom Henrique os levou a isso com a pertinácia dąs suas navegações. Nessas buscas Portugal procura encontrar o reino do famoso Prestes João. Em textos franceses fala-se em Prestes João na Asia. O papado enviou diversos monges com a missão de encontrá-lo. Houve certo momento em que os ocidentais tiveram a ingenuidade de pensar na conversão dos tártaros. Talvez issso seja obra de missionários nestorianos no Turquestão e na China: O reino de Prestes João provàvelmente é êsse reino da Abissínia, na região do Mar Vermelho, que há muito tempo era cristão, mas de rito copta. A busca de Prestes Joño se fêz por terra e mar. Por terra temos Covilhã e por mar a epopéia de Vasco da Gama. Pouco a pouco restabeleceu-se novamente a rota do Extremo Oriente, desta vez por Portugal que inundou a Europa de pimenta e demais especiarias com suas navegações rumo à fndia.

\section{E. SIMÓES DE PAULA}

Professor de Hístória da Civilização Antiga e Medieval da Faculdade de Filosofia; Ciências e Letras da Universidade de São Paulo. 